obrady a co najważniejsze wydali pożyteczne materiały, które mogą stanowić ważny przyczynek do szczegółowszego określenia roli i zadań OHP w nowej rzeczywistości politycznej i społecznej, w pogłębiających się zjawiskach patologicznych wśród młodzieży, wobec postępującej destrukcji życia rodzinnego i zrzucania $\mathrm{z}$ siebie przez rodziców na społeczeństwo najważniejszego obowiązku, który do nich należy, tj. obowiązku wychowania swych dzieci.
Sądzić należy także, że OHP i ich decydenci dostrzegą potrzebę systematycznych prac badawczych i naukowego wsparcia pracy nad wychowaniem młodzieży i powołaja w tym celu odpowiednie centrum naukowe.

\section{Jan Hellwig}

1 J. Hellwig 40-lecie OHP. Konferencja naukowa w Glucholazach, 26-28.03.1998 r. „Biuletyn Historii Wychowania" 1998, nr 1-2(7-8), s. 76-78.

\title{
Slownik pedagogów polskich, pod red. Wandy Bobrowskiej-Nowak i Danuty Dryndy, Katowice 1998, ss. 243
}

Slownik pedagogów polskich to wydawnictwo, którego inicjatywe i ostateczny ksztalt zawdzięczamy pracownikom Katedry Podstaw Pedagogiki i Historii Wychowania Uniwersytetu Śląskiego. Tam bowiem przebiegały prace koncepcyjne i organizacyjne nad Slownikiem. Idea tego typu opracowania, jak piszą we Wstępie Redaktorki W. Bobrowska-Nowak i D. Drynda, powstała w toku prowadzonych w Katedrze badań nad dziejami polskiej myśli wychowawczej. Poparli ją pedagodzy i historycy wychowania $z$ większości ośrodków naukowych, którzy sq autorami zamieszczonych biogramów. To dowodzi słuszności powstania takiego opracowania, z jednej strony, z drugiej zaś, podnosi rangę wydawnictwa gwarantując wysoki poziom publikacji.

Na strukturę Slownika składa się 250 haseł biograficznych pedagogów nieżyjących. Przyjęta tutaj została szeroka definicja pedagoga, gdyż na liście osób umieszczonych w tym opracowaniu znajdują się nie tylko pedagodzy sensu stricte, ale i filozofowie, etycy, socjolodzy, psycholodzy, teolodzy, a nawet lekarze, którzy w swojej twórczości i działalności zajmowali się problematyka pedagogiczną. Przy czym wzięto pod uwage te osoby, które niezależnie od swej podstawowej specjalizacji przyczyniły się swoimi pracami w istotny sposób do rozwoju nauk o wychowaniu. Ponadto dodatkowym kryterium doboru było wyższe wykształcenie z pedagogiki lub dyscyplin współdziałających $\mathrm{z}$ pedagogiką.
Slownik obejmuje czasy od drugiej połowy XVIII wieku do 1996 roku. W uzasadnionych przypadkach sięgano do wcześniejszych lat, sprzed I polowy XVIII wieku. Zaopatrzony jest także w Bibliografie w wyborze zamieszczoną na końcu publikacji, w której znajdziemy informacje 0 podstawowych pracach wykorzystanych przez autorów biogramów.

Tego Slownika, jak i każdego innego, nie można traktować jako źródła systematycznej wiedzy o przedmiotowej rzeczywistości. Należy on do wydawnictw o charakterze informacyjnym i to jest podstawowa jego funkcja, którą spełnia. Lecz spełnia także funkcję integracyjną wewnątrz nauk o wychowaniu, jak i w stosunku do dyscyplin pokrewnych. Jako publikacja słownikowa o charakterze historyczno-biograficznym stanowi doskonałe uzupelnienie innych tego typu pozycji (słowników, encyklopedii, leksykonów) dostępnych na naszym rynku wydawniczym.

W sumie Slownik pedagogów polskich jest opracowaniem, które przez pryzmat biografii zarysowuje dzieje polskiej pedagogiki, ukazując jej twórców i przedstawicieli, a przede wszystkim jej różnorodne źródła i powiązania $z$ innymi dyscyplinami wiedzy. Dzięki temu widoczny jest udział innych specjalistów w kształtowaniu problematyki badawczej z zakresu pedagogiki i jej metodologii badań.

Wykorzystując biogramy można także poznać najważniejsze idee polskiej myśli wycho- 
wawczej, ich rozwój i ewolucję na przestrzeni dziejów. Można szukać odpowiedzi na pytanie - związki polskiej pedagogiki $z$ europejska myślą wychowawczą. A zapoznając $\mathrm{z}$ najważniejszymi przejawami indywidualnego rozwoju poszczególnych myślicieli możemy stworzyć zarys portretu środowiska pedagogów polskich.

Traktując niniejszą recenzję jako głos w dyskusji (do czego zachęcają Redaktorki) nad publikacja, pozwalam sobie na kilka uwag, które naturalnie mają charakter dyskusyjny.

Bowiem skoro już z opisu struktury i założeń Slownika wynika, iż polską pedagogikę tworzyli także przedstawiciele innych dyscyplin, może wskazane byłoby przy następnej edycji zaangażować do współpracy także innych specjalistów, nie tylko pedagogów i historyków. To przysporzyłoby wielu trudności, zwłaszcza natury organizacyjnej, ale być może byłoby z korzyścią dla opracowania.

Druga uwaga dotyczy w pewnym sensie struktury biogramów. Jeśli przyjmujemy, że
Slownik odzwierciedla aktualny stan wiedzy o historii pedagogiki i jej rozwoju, czy nie lepiej byłoby pod każdym biogramem podać źródła wiedzy o pedagogu? To miałoby znaczenie dla następnego wydania, w którym widoczna byłaby aktualizacja wiedzy.

Trzecie spostrzeżenie odnosi się do pominiętego podczas korekty błędu dotyczącego daty urodzenia i ukończenia studiów $\mathbf{M}$. Węglewicza (s. 215 -216). To jednak przy tego typu wydawnictwach jest nie do uniknięcia.

W sumie to zbiorowe dzieło polskiego środowiska naukowego jest cenną inicjatywą świadczącą o jego aktywności w sferze działań na rzecz rozwoju nauk o wychowaniu. Jest także przykładem starań o zachowanie dyscypliny metodologicznej wyrażającej się w konsekwencji wobec przyjętych zalożeń projektu badawczego. To niewątpliwie zawdzięczamy nie tylko autorom biogramów, ale Redakcji Slownika.

\section{Noty}

Erfolg. Niedergang. Neuanfang. 100 Jahre Verband Deutscher Sondarschulen - Fachverband für Behinderten - Pädagogik. Im Aftrag des Verbandes herausgegeben von Andreas Möckel mit Beiträgen von Herwig Baier, Elrich Bleidick, Bodo Bröse, Sieglind Ellgar-Rüttgard, Clemens Hillenbrand, Gustav Kanter, Christian Lindmeier, Andreas Möckel, Norbert Myschker, Bruno Prändl, Franz Rumpler, Ditmar Schmetz, Otto Speck, Ursula Stinkes, Norbert Stoellger, Peter Wachtel. Ernst Reinhardt Verlag München - Basel 1998, ss. 602

Z okazji obchodów 100-lecia Niemieckiego Towarzystwa Szkół Specjalnych (Verband Deutscher Sonderschulen) - zawodowej organizacji pedagogów specjalnych ukazała się praca zbiorowa pod powyższym tytułem. Książka jest zarysem historycznym kształtowania się ruchu pedagogicznego począwszy od konferencji dotyczących pracy z idiotami (Die Konferenz für 